\title{
The Relationship between Lexical Inferencing Strategies and L2 Proficiency of Iranian EFL Learners
}

\author{
Mansoor Tavakoli \\ Department of English, University of Isfahan, Iran \\ Email: mr.tavakoli14@gmail.com \\ Samira Hayati \\ Department of English, University of Isfahan, Iran \\ Email: Sr.hayati.2006@gmail.com
}

\begin{abstract}
This paper tries to find out what knowledge sources Iranian EFL learners used while trying to infer the meaning of unknown words in the context. It is also intended to find out whether the students' level of $\mathrm{L2}$ proficiency would affect the pattern of their use of the knowledge sources, and if there is a relationship between students' lexical inferencing strategy and their sex. To conduct the study, forty Iranian EFL learners, studying English at the private language institute, were selected to participate in the experiment, and then, they were divided into low and high intermediate levels based on their scores on FCE test. Four short stories were given to them, each story in one class session. The participants were asked to read the story, underline the unknown words, guess the meaning of those unknown words, and then specify the knowledge sources that they used to guess the meaning of the unknown words. The results showed that there were some differences among the students at these two levels regarding the type of knowledge sources used and success in lexical inferencing.
\end{abstract}

Index Terms-EFL learners, gender, L2 proficiency, lexical inferencing strategies, reading comprehension, vocabulary knowledge

\section{INTRODUCTION}

Learning vocabulary in a second language is an important and complex task. Many scholars believe that learning a second language (L2) involves the learning of large numbers of words (Avila \& Sadoski, 1996; Laufer\& Hulstijn, 2001). In fact, it is believed that vocabulary learning is one of the most integral and fundamental areas of language acquisition, whether dealing with L1 or L2. Effective second language vocabulary acquisition is particularly important for English as foreign language (EFL) learners who frequently acquire impoverished lexicons despite years of formal study (Hunt \& Beglar, 2005).

Vocabulary is important since it is the words which carry the content of what we want to express. But how do the learners acquire vocabulary is of utmost importance in language learning. It is said that reading is probably one of the best ways to acquire new vocabularies. However, L2 vocabulary development through reading is complex. One of the most difficulties learners have in reading is about vocabulary. When reading different passages in a foreign language, the learners come across unfamiliar words which inhibit their understanding of them. There are a number of ways to find out the meaning of unfamiliar words such as consulting a dictionary, asking someone and inferring the meaning from the context. In language learning, inferring word meanings while reading is a process of vocabulary acquisition which has an important influence on comprehension either in first or second language. Inferencing has been defined as the connections that people establish when they try to interpret texts (Brown \& Yule, 1983).

To further shed light on this issue, the present study tries to investigate the relationship between types of knowledge sources and lexical inferencing of Iranian EFL learners across different levels of proficiency.

\section{THEORETICAL BACKGROUND}

A widely held view in the current literature on second and/or foreign language acquisition is that one major way in which learners acquire different kinds of language knowledge, such as syntactic knowledge, semantic knowledge, is through exposure to and comprehension of oral and written input in L2. Nowadays, much attention has been paid to reading by teachers and researchers either in a second or foreign language learning contexts. Also, for many students, reading is the most important of the four language skills. This point becomes more important especially in EFL learning situations since reading turns into one of the main sources of input by which learners learn the new language. Extensive 
reading gives learners rich background knowledge, vocabulary recognition, familiarity with the structure and rhetorical conventions of different texts and high motivation for reading more.

Skills in reading fall generally into four categories: mechanics, syntax, vocabulary, and comprehension. To comprehend a text is the main purpose of reading. Reading comprehension is a complex skill which involves combining all of the reading subskills to get the message of the text. During EFL reading process, many a factor influences a reader's comprehension of the text. Among them, lexical problems have been considered as the most serious (Chern and Chi, 1988; Grabe, 1991; Levine and Reves, 1990; Walker, 1981; Yorio, 1971). Since vocabulary is a sizable component in the learning process, learners across proficiency levels will encounter situations where they can understand only part of the text due to the fact that they do not know the meaning of all the words in the text. Most research in vocabulary learning indicates that learners can derive the meaning of unknown words while reading by using the context in which they appear (Chern, 1993; Day, Omura, \& Hiramatsu, 1991; Seibert, 1945; Stein, 1993). Second language (L2) vocabulary development through reading involves associating new forms with their meanings and referents using syntactic, semantic and pragmatic knowledge.

Guessing intelligently in reading, sometimes called "inferencing", involves using a variety of linguistic and nonlinguistic clues to guess the meaning when the learner does not know all the words (Oxford, 1990). But there seems to be a number of factors which can affect success in inferencing the meaning of unknown words from the context. Bensoussan and Laufer (1984) concluded:

Lexical guessing is a very difficult task either because of the complexity of the text or because of the limitations of the reader, or both. Some words do not have clues in the text in which they appear; when there are clues for such words foreign language learners will not necessarily look for them; and when readers do look for these clues very often they cannot locate or understand them. (p. 27)

Since adequate cues in the context can help learners to infer the meaning of unfamiliar words, it might follow that reasonably sufficient contextual cues should be provided in texts for foreign language learners, so that enough information can be created for them to play the "psycholinguistic guessing game" which requires " skill in selecting the fewest, most productive cues necessary to produce guesses which are the first time" (Goodman, 1967, p.128).

Robinson and Good (1987) classified seven types of cotextual clues used by EFL readers to solve word problems in reading comprehension. The seven types are definition, experience, comparison or contrast, synonym, familiar expression or language experience, summary, and mood or situation. Sentence connectives were added by Kruse (1979), appositives by Durkin (1989), and hyponyms by Mikulecky (1990).

Haastrup's (1990) study of Danish-speaking EFL readers demonstrated that EFL readers utilize a wide range of lexical inferencing procedures, but most of them are used ineffectively. For instance, some readers adopt pure bottomlevel processing and work exclusively at the morphological identification, and some readers rely on pure top-level contextual clues only and disregard the possible semantic or lexical sources. Haastrup (1990) states that EFL readers' knowledge of how to comprehend new words is basically established on readers' linguistic and conceptual knowledge. Her analysis of the differences between high-proficiency and low- proficiency readers further proved that reader's L2 proficiency is a "decisive factor in lexical inferencing procedure." What Haastrup informed us is that successful lexical inferencing depends on all available contextual clues, readers' L2 proficiency, readers' general knowledge of the world, and the parallel processing of word meaning, i.e., the interactive model of bottom-level and top-level.

To explore how EFL learners cope with unknown words, Nation (1990) indicated that word guessing form the context is undoubtedly the most significant vocabulary learning strategy. Lexical inferencing from contextual clues, as Nation proposed, enables learners to make a well-formed guess at the meaning of an unfamiliar word in context without interrupting their own train of thought too much.

About factors involved in lexical inferencing, Nagy (1997) considers the role of learners' pre-existing knowledge bases and how these knowledge bases influence learners' strategy use and success. Nagy groups learners' knowledge bases into three main categories: linguistic knowledge, world knowledge and strategic knowledge. The linguistic knowledge category covers all knowledge that learners possess about the linguistic context in which the word has occurred, including their syntactic knowledge, lexical knowledge, and knowledge of word schema (i.e., knowledge of possible meanings of the word). Nassaji (2004) concluded that there is a significant link between depth of vocabulary knowledge and the type and degree of lexical inferencing strategy use.

Riazi and Babaei (2008) conducted a study to reveal Iranian EFL female students' lexical inferencing and its relationship to their L2 proficiency and reading skill. The results of their study showed that elementary students resorted to all clues including contextual, intralingual and interlingual to guess the meaning of unknown words, while intermediate students relied on contextual clues only and advanced learners made use of contextual and intralingual (just in one case) sources and also advanced students were more successful in making correct lexical inferences. They further concluded that lexical inferencing ability did not show any significant relationship with students' reading comprehension performance.

İstifçi (2009) examined lexical inferencing of Turkish EFL learners. He wanted to show what inferencing strategies the learners at intermediate and low- intermediate levels use when they attempt to guess the meaning of unknown words and the similarities and differences between these two levels. It was seen that students at the two levels tried to use 
different types of inferencing strategies. However, the percentage of correct inferences was higher at intermediate level than low-intermediate level.

This can be due to the students' level and the degree of risk-taking. Also, it was shown that the students at intermediate level were more successful than the students at low-intermediate level in their guesses of the meaning of unknown words. It was observed that the students at intermediate level considered the whole passage and tried to get its main idea, whereas the students at low-intermediate level focused on individual words and attempted to guess their meaning.

In the current study, expanding on this line of research, we tried to discover the type of knowledge sources that Iranian EFL learners at high and low intermediate level use to guess the meaning of unknown words and differences between the students at these two levels in terms of the type of knowledge sources used and success in guessing. We also investigated the potential effect of gender on lexical inferencing. Since no other study was found in the literature to examine the effect of sex on lexical inferencing, it can be said that this study is the first one in this regard.

\section{THE PRESENT STUDY}

Having reviewed previous studies on lexical inferencing, a replication study was conducted in an EFL context, Iran, to address the following questions:

1. What type of knowledge sources do high-intermediate and low-intermediate Iranian EFL learners use to infer the meaning of unknown words from the context? It is hypothesized that there are differences between the students at these two levels in terms of the type of knowledge sources that they use in lexical inferencing.

2. Are there any differences between the learners at these two levels in terms of correct guessing and use of knowledge sources? It seems that the high proficient students may be more successful in inferring the meaning of unknown words.

3. Can gender have any potential effect on the use of knowledge sources and success in guessing the meaning? It is assumed that sex do not have any potential effect on the use of knowledge sources and success in lexical inferencing.

\section{METHOD}

\section{A. Participants}

The population from which the participants were chosen included the EFL learners who were enrolled in a language institute in Isfahan. To divide the participants into high and low intermediate levels, first the FCE was given to them, and then based on their scores forty students were selected. As a result, twenty high-intermediate level students (8 female and 12 male) and twenty low- intermediate level students (11 female and 9male) participated in this study.

\section{B. Instruments}

Two instruments were used in this study: FCE test, and four reading passages. The reason for the use of FCE test was twofold: first to select the intended participants, and second to divide them into low and high-intermediate levels (see Appendix A).

In order to find the type of inferencing strategies and knowledge sources used by EFL learners to guess the meaning of unknown words, those four reading passages were chosen for the study (see Appendix B). To motivate the participants to take the reading task eagerly, the four passages were funny short stories. The short stories were read in their usual class sessions, one at a time by the students and their usual teachers assigned them in class.

\section{Data Collection Procedure}

Data were collected in four consecutive weeks. Each week in one session, the students were asked to read one of the passages and underline the unknown words, then to guess the meaning of unknown words. After carrying out these steps, they wrote about how they guessed the meaning of unknown words, what strategies they used in guessing, and what helped them to guess the meanings in passages. They could write the meanings of words both in English and in Persian. At the end of the forth week, all the data were checked and categorized according to Paribakht and Wesche's (1999) classification. The categorization is as follows:

1. Homonymy: As Paribakht \& Wesche, (1999, p.209) state learners use their knowledge of sound relationships or the phonetic similarity between the target word and another word in the learners' mental lexicon to guess the meaning of an unknown word. The association may be with an L1 word or another L2 word and is often misleading.

2. Morphology: This category includes knowledge of derivations and grammatical inflections.

3. Word associations: They include paradigmatic relations (e.g. synonyms or antonyms), syntagmatic relations (e.g. words in the same category), and members of the same taxonomy (superordinates, subordinates, coordinates).

4. Sentence-level grammatical knowledge: This category includes knowledge of relationships in the sentence such as word-class information and syntactic category of the word.

5. Discourse knowledge: It includes using information from beyond sentence boundaries such as the knowledge of cohesive devices and establishing semantic links. 
6. Cognates: As Richards et al. (1985) state "cognates are words in one language which is similar in form and meaning to a word in another language" (Richards et al., 1985, p.43).

7. World knowledge: This category is related to the familiarity of the theme and topic of the text to the learner.

8. Punctuation: This refers to mechanics of writing.

\section{Data Analysis}

In analyzing the data, the grammatical classes of the underlined words were not taken into consideration since the focus of this study was to find the lexical inferencing strategies used by the EFL learners. All the inferences gathered from high-intermediate and low-intermediate level students, either correct or incorrect, were counted and categorized for each level to have an overall idea of the inferences. Then the correct inferences were counted, their percentages were taken, and the knowledge sources used by the students at high-intermediate level and low-intermediate level were compared. The data were analyzed according to Paribakht and Wesche's classification as noted above with one modification. That is, punctuation category was not included since it was not used by the students who participated in this study.

\section{RESULTS}

To investigate the hypothesized relationships among the variables under study such as knowledge sources, lexical inferencing strategies, levels of proficiency, and gender differences, the analysis of the data yielded a number of results which will be reported in this section.

As shown in Table-1 below, for the first reading passage, the students at low-intermediate level made a total of 108 inferences (42 of them were correct, 39\%), whereas the students at high-intermediate level made a total of 87 inferences (57of them were correct, $66 \%$ ).

TABLE-1:

INFERENCES USED BY LOW-INTERMEDIATE AND HIGH-INTERMEDIATE LEVEL STUDENTS FOR PASSAGE 1

\begin{tabular}{|c|c|c|c|c|c|c|c|c|c|c|c|c|c|c|c|c|}
\hline & \multicolumn{2}{|c|}{ Homonymy } & \multicolumn{2}{|c|}{ Morphology } & \multicolumn{2}{|c|}{$\begin{array}{l}\text { Word- } \\
\text { association }\end{array}$} & \multicolumn{2}{|c|}{$\begin{array}{l}\text { Sentence- } \\
\text { level } \\
\text { grammatical } \\
\text { knowledge }\end{array}$} & \multicolumn{2}{|c|}{$\begin{array}{l}\text { Discourse } \\
\text { knowledge }\end{array}$} & \multicolumn{2}{|c|}{ Cognate } & \multicolumn{2}{|c|}{$\begin{array}{l}\text { World } \\
\text { knowledge }\end{array}$} & \multicolumn{2}{|c|}{ Total } \\
\hline & $\mathrm{n}$ & $\%$ & $\mathrm{n}$ & $\%$ & $\mathrm{n}$ & $\%$ & $\mathrm{n}$ & $\%$ & $\mathrm{n}$ & $\%$ & $\mathrm{n}$ & $\%$ & $\mathrm{n}$ & $\%$ & $\mathrm{~N}$ & $\%$ \\
\hline All inferences LI & 9 & 8 & 27 & 25 & 8 & 7.5 & 34 & 32 & 9 & 8 & 7 & 6.5 & 14 & 13 & 108 & 100 \\
\hline Correct inferences LI & 0 & 0 & 10 & 24 & 5 & 12 & 14 & 33 & 3 & 7 & 5 & 12 & 5 & 12 & 42 & 100 \\
\hline All inferences HI & 1 & 1 & 10 & 11.5 & 14 & 16 & 10 & 11.5 & 28 & 32 & 5 & 6 & 19 & 22 & 87 & 100 \\
\hline Correct inferences HI & 0 & 0 & 5 & 9 & 9 & 16 & 5 & 9 & 19 & 33 & 5 & 9 & 14 & 24 & 57 & 100 \\
\hline
\end{tabular}

As shown in Table-2, for the second reading passage, the students at low-intermediate level made a total of 128 inferences (65 of them were correct, $51 \%)$ and the students at high-intermediate level made a total of 107 inferences (81 of them were correct, $76 \%$ ).

TABLE-2:

INFERENCES USED BY LOW-INTERMEDIATE AND HIGH-INTERMEDIATE LEVEL STUDENTS FOR PASSAGE 2

\begin{tabular}{|c|c|c|c|c|c|c|c|c|c|c|c|c|c|c|c|c|}
\hline & \multicolumn{2}{|c|}{ Homonymy } & \multicolumn{2}{|c|}{ Morphology } & \multicolumn{2}{|c|}{$\begin{array}{l}\text { Word- } \\
\text { association }\end{array}$} & \multicolumn{2}{|c|}{$\begin{array}{l}\text { Sentence-level } \\
\text { grammatical } \\
\text { knowledge }\end{array}$} & \multicolumn{2}{|c|}{$\begin{array}{l}\text { Discourse } \\
\text { knowledge }\end{array}$} & \multicolumn{2}{|c|}{ Cognate } & \multicolumn{2}{|c|}{$\begin{array}{l}\text { World } \\
\text { knowledge }\end{array}$} & \multicolumn{2}{|c|}{ Total } \\
\hline & n & $\%$ & $n$ & $\%$ & $n$ & $\%$ & n & $\%$ & $n$ & $\%$ & $n$ & $\%$ & $\mathrm{n}$ & $\%$ & $n$ & $\%$ \\
\hline All inferences LI & 3 & 2 & 29 & 23 & 12 & 9 & 38 & 30 & 23 & 18 & 9 & 7 & 14 & 11 & 128 & 100 \\
\hline Correct inferences LI & 0 & 0 & 15 & 23 & 7 & 11 & 19 & 29 & 6 & 9 & 9 & 14 & 9 & 14 & 65 & 100 \\
\hline All inferences HI & 2 & 2 & 11 & 10 & 17 & 16 & 14 & 13 & 37 & 34.5 & 7 & 6.5 & 19 & 18 & 107 & 100 \\
\hline Correct inferences HI & 1 & 1 & 4 & 5 & 12 & 15 & 9 & 11 & 33 & 41 & 6 & 7 & 16 & 20 & 81 & 100 \\
\hline
\end{tabular}

For the third reading passage, the students at low-intermediate made a total of 116 inferences ( 60 of them were correct, 52\%) and the students at high-intermediate level made a total of 98 inferences (75 of them were correct, $77 \%$ ), see table 3.

TABLE-3:

INFERENCES USED BY LOW-INTERMEDIATE AND HIGH-INTERMEDIATE LEVEL STUDENTS FOR PASSAGE 3

\begin{tabular}{|c|c|c|c|c|c|c|c|c|c|c|c|c|c|c|c|c|}
\hline & \multicolumn{2}{|c|}{ Homonymy } & \multicolumn{2}{|c|}{ Morphology } & \multicolumn{2}{|c|}{$\begin{array}{l}\text { Word- } \\
\text { association }\end{array}$} & \multicolumn{2}{|c|}{$\begin{array}{l}\text { Sentence-level } \\
\text { grammatical } \\
\text { knowledge }\end{array}$} & \multicolumn{2}{|c|}{$\begin{array}{l}\text { Discourse } \\
\text { knowledge }\end{array}$} & \multicolumn{2}{|c|}{ Cognate } & \multicolumn{2}{|c|}{$\begin{array}{l}\text { World } \\
\text { knowledge }\end{array}$} & \multicolumn{2}{|c|}{ Total } \\
\hline & $\mathrm{n}$ & $\%$ & $\mathrm{n}$ & $\%$ & $\mathrm{n}$ & $\%$ & $\mathrm{n}$ & $\%$ & $\mathrm{n}$ & $\%$ & $\mathrm{n}$ & $\%$ & $\mathrm{n}$ & $\%$ & $\mathrm{~N}$ & $\%$ \\
\hline All inferences LI & 6 & 5 & 25 & 21 & 10 & 9 & 37 & 32 & 16 & 14 & 6 & 5 & 16 & 14 & 116 & 100 \\
\hline Correct inferences LI & 0 & 0 & 14 & 23 & 3 & 5 & 27 & 45 & 6 & 10 & 3 & 5 & 7 & 12 & 60 & 100 \\
\hline All inferences HI & 1 & 1 & 10 & 10 & 15 & 15.5 & 12 & 12 & 35 & 36 & 5 & 5 & 20 & 20.5 & 98 & 100 \\
\hline Correct inferences HI & 1 & 1 & 7 & 9 & 11 & 15 & 8 & 11 & 28 & 37 & 5 & 7 & 15 & 20 & 75 & 100 \\
\hline
\end{tabular}


As it can be seen in Table-4, for the forth reading passage, the students at low-intermediate level made a total of 93 inferences ( 44 of them were correct, $47 \%$ ), whereas the students at high-intermediate level made a total of 85 inferences (59 of them were correct, $69 \%$ ).

TABLE-4:

INFERENCES USED BY LOW-INTERMEDIATE AND HIGH-INTERMEDIATE LEVEL STUDENTS FOR PASSAGE 4

\begin{tabular}{|c|c|c|c|c|c|c|c|c|c|c|c|c|c|c|c|c|}
\hline & \multicolumn{2}{|c|}{ Homonymy } & \multicolumn{2}{|c|}{ Morphology } & \multicolumn{2}{|c|}{$\begin{array}{l}\text { Word- } \\
\text { association }\end{array}$} & \multicolumn{2}{|c|}{$\begin{array}{l}\text { Sentence- } \\
\text { level } \\
\text { grammatical } \\
\text { knowledge }\end{array}$} & \multicolumn{2}{|c|}{$\begin{array}{l}\text { Discourse } \\
\text { knowledge }\end{array}$} & \multicolumn{2}{|c|}{ Cognate } & \multicolumn{2}{|c|}{$\begin{array}{l}\text { World } \\
\text { knowledge }\end{array}$} & \multicolumn{2}{|c|}{ Total } \\
\hline & $\mathrm{n}$ & $\%$ & $\mathrm{n}$ & $\%$ & $\mathrm{n}$ & $\%$ & $\mathrm{n}$ & $\%$ & $\mathrm{n}$ & $\%$ & $\mathrm{n}$ & $\%$ & $\mathrm{n}$ & $\%$ & $\mathrm{~N}$ & $\%$ \\
\hline All inferences LI & 4 & 4 & 17 & 18 & 8 & 9 & 31 & 33 & 12 & 13 & 8 & 9 & 13 & 14 & 93 & 100 \\
\hline Correct inferences LI & 0 & 0 & 10 & 23 & 4 & 9 & 16 & 36 & 3 & 7 & 6 & 14 & 5 & 11 & 44 & 100 \\
\hline All inferences HI & 0 & 0 & 9 & 11 & 14 & 16 & 11 & 13 & 30 & 35 & 4 & 5 & 17 & 20 & 85 & 100 \\
\hline Correct inferences HI & 0 & 0 & 4 & 7 & 10 & 17 & 6 & 10 & 24 & 41 & 2 & 3 & 13 & 22 & 59 & 100 \\
\hline
\end{tabular}

Using Paribakht and Wesche's classification, we investigated the research questions regarding the subjects' lexical inferencing strategies. The results will be explained in order.

In terms of ' homonymy' category, it was seen that the subjects at low-intermediate level tried to infer the meanings of unknown words by using more sound relations between words in L2 and all their guesses were incorrect. This finding is consistent with the claim that students with low proficiency in L2 often try to associate new words by using phonetic similarities. The subjects made wrong guesses such as 'remain' for the word 'remind', 'apparent' for the word 'appear', 'weather' for the word 'whether', 'big' for the word 'beg', 'forest' for the word ' famous'. The subjects at highintermediate level employed this category for 4 guesses, and just 2 of them were correct.

In terms of 'morphology' category, it was used for 27 of 108 cases in passage 1 (10 correct guesses), 29 of 128 cases in passage 2 (15 correct guesses), 25 of 116 cases in passage 3 (14 correct guesses) and 17 of 93 cases in passage 4 (10 correct guesses) by the students at low-intermediate level. On the other hand, the students at high-intermediate level employed this category 10 of 87 cases in passage 1 (5 correct guesses), 11 of 107 cases in passage 2 (4 correct guesses), 10 of 98 cases in passage 3 ( 7 correct guesses) and 9 of 85 cases in passage 4 (4 correct guesses).

From the data, it can be said that the subjects at low-intermediate level tried to infer the meanings of unknown words by considering their inflections, derivations, i.e. morphological relationships between words, and they were successful in using this inferencing strategy.

The 'word- association' category accounted for 8 of 108 cases in passage 1 ( 5 correct guesses), 12 of 128 cases in passage 2 ( 7 correct guesses), 10 of 116 cases in passage 3 ( 3 correct guesses) and 8 of 93 cases in passage 4 (4 correct guesses) at low-intermediate level data. However, the students at high-intermediate level used this category 14 of 87 cases in passage 1 ( 9 correct guesses), 17 of 107 cases in passage 2 (12 correct guesses), 15 of 98 cases in passage 3 (11 correct guesses) and 14 of 85 cases in passage 4 (10 correct guesses). It was seen that high-intermediate level students tried to establish associations of the words by using synonyms and antonyms more than low-intermediate level students. This observation compatibly fits with prior research findings in this vein (İstifçi, 2009). It is suggested in the literature that more proficient L2 learners make more word-associations than less proficient learners, and their guesses are often more correct than less proficient students'.

In terms of 'sentence-level grammatical knowledge' category, it was seen that the subjects at low-intermediate level tried to guess the meanings of unknown words by looking at the grammatical category of words: 34 of 108 cases in passage 1 (14 correct guesses), 38 of 128 cases in passage 2 (19 correct guesses), 37 of 116 in passage 3 (27 correct guesses) and 31 of 93 in passage 4 (16 correct guesses). The students at high-intermediate level, on the other hand, employed this category 10 of 87 cases in passage 1 (5 correct guesses), 14 of 107 cases in passage 2 ( 9 correct guesses), 12 of 98 cases in passage 3 ( 8 correct guesses) and 11 of 85 cases in passage 4 (6 correct guesses).

The ' discourse knowledge' category was the one which was mostly used by the students at high-intermediate level. Not only did the students at high-intermediate level use this category more than the students at low-intermediate level, but also the percentage of their correct guesses was higher than that of less proficient students.

The subjects at low-intermediate level used this category 9 of 108 cases in passage 1 ( 3 correct guesses), 23 of 128 cases in passage 2 ( 6 correct guesses), 16 of 116 cases in passage 3 ( 6 correct guesses), and 12 of 93 cases in passage 4 (3 correct guesses). The students at high-intermediate level employed this category 28 of 87 cases in passage 1 (19 correct guesses), 37 of 107 cases in passage 2 (33 correct guesses), 35 of 98 cases in passage 3 ( 28 correct guesses) and 30 of 85 cases in passage 4 ( 24 correct guesses). It can be said that the students used their knowledge of cohesive devices to link the words in the texts, and considered units larger than sentence to guess the meanings of unknown words. The difference between the students at two levels was more salient in passage 2 that the students at highintermediate level made 33 correct guesses whereas the students at low-intermediate level made 6 correct guesses.

In terms of 'cognates', the students at low-intermediate level used more cognates to infer the meanings of unknown words than the students at high-intermediate level. For passage 1, the students at low-intermediate level made 7 guesses ( 5 of them were correct), for passage 2, 9 guesses (all of them were correct), for passage 3, 6 guesses ( 3 of them were correct) and for passage 4, 8 guesses (6 of them were correct), whereas the students at high-intermediate level made 5 guesses for both passage 1 and passage 3 and all of them were correct. For passage 2, 7 guesses were made (6 correct 
ones) and for passage 4, 4 guesses were made (2 correct ones). The students used the words that were similar to the words in their L1 such as 'heater', 'balcony', 'battery', 'festivities'.

The 'world knowledge' was another category which the students at high-intermediate level used more than the students at low-intermediate level, and also they were more successful than the students at low-intermediate level. The students at low-intermediate level made 14 guesses in passage 1 ( 5 of them were correct), whereas the students at highintermediate level made 19 guesses (14 of them were correct). For the passage 2, the students at low-intermediate level made 14 guesses ( 9 of them were correct), while the students at high-intermediate level made 19 guesses (16 of them were correct).

For passage 3, the students at low-intermediate level made 16 guesses ( 7 of them were correct), whereas the students at high-intermediate level made 20 guesses (15 of them were correct). For passage 4 , the students at low-intermediate level made 13 guesses ( 5 of them were correct), while the students at high-intermediate level made 17 guesses (13 of them were correct).

It should be noted that none of the students used the 'punctuation' category, so it was not included in the analysis.

\section{DISCUSSION AND CONCLUSION}

As a result of data analysis, a number of findings emerged that will be delineated and discussed in this section. When considering all the lexical inferences made by the students, it can be said that the students at high-intermediate level were more successful than the students at low-intermediate level in guessing the meaning of unknown words. The finding that the students at high-intermediate level were more successful in making correct lexical inferences is consistent with the findings of the studies conducted by Lee and Wolf (1997) and Nassaji (2004). Nassaji's (2004) findings indicated that lexical inference is significantly influenced by the richness of the learner's pre-existing semantic system. This system develops cumulatively; therefore, such richness is brought about gradually as the learner's proficiency improves. It can be said that the students at the two levels tried to use a wide variety of inferencing strategies.

The students used almost all the categories except punctuation category; however, the percentage of correct guesses was higher at high-intermediate level than low-intermediate level.

Low-intermediate level students tried to associate the unknown words with the words they already knew, and some of their guesses were wrong. As Levin et al. (1979) (cited in Lawson \& Hogben, 1996) state, the foreign language learners who are quite early in their foreign language studies acquire vocabulary using mnemonic techniques or strategies which involve cognates and phoneme correspondences.

When analyzing the data, it was found that the students at low-intermediate level used 'sentence-level grammatical knowledge' category most frequently, and from this finding it can be said that the students at low-intermediate level concentrated more on the words and syntactic category of the words while reading the passages and tried to guess the meanings of unknown words. They needed to know the meanings of all words in the passage to understand it

On the other hand, the students at high-intermediate level, both male and female, used 'discourse knowledge' category the most and tried to find the meanings of unknown words by considering the whole passage. They tried to understand the whole passage by looking at the context, and getting the general idea of the passage. It is suggested in the literature that more proficient students find associations more easily and establish a network of associations when they see or hear a word than low-ability students (Kess, 1992; Richards, 1991).

As Kern (1989) states more advanced learners use the context in order to decide the meaning of an unknown word, try to make guesses on the basis of what is familiar to them, and they are more successful than low-ability learners. Nassaji (2006) claims that those learners who possess a deeper lexical knowledge have better access to the knowledge sources and, hence, can construct a more accurate semantic representation of the unknown word during lexical inferencing than those who do not. Haynes (1993) claims that L2 readers are apt to mis-recognize new forms as familiar ones, and other authors point out the problems of form confusion for L2 readers. For example, Huckin and Bloch (1993) found the most serious mistakes in L2 word inferencing were caused by mistaken identity, and if word recognition is uncertain, the effectiveness of inferencing must be impaired. Schmitt \& Meara (1997) also found that L2 readers were apt to mistake a lower frequency word for a higher frequency one with a similar form.

It is noteworthy that it seemed to be no difference between the male and female students regarding the type of inferencing strategy used and the success in their guesses. Both male and female students at low-intermediate level used 'sentence-level grammatical knowledge' the most, and both male and female students at high-intermediate level mostly used 'discourse knowledge'. In terms of their success, no difference was found depending on the students' sex.

Based on the findings obtained in this study, a number of implications are drawn which can possibly assist language practitioners and teachers in the EFL context. First and foremost, language teachers can involve their students with such tasks in the classroom so as to boost their vocabulary knowledge at both receptive and productive levels. Second, students can be exposed to different types of authentic reading passages and encouraged to guess the meaning of unknown words.

Another one is that, while teaching students to guess the meaning of unknown words, teachers should warn them to consider the whole sentence and not to rely on individual words, since the context can affect the meaning of words. 


\section{Part 1}

You are going to read a newspaper article about bookshops which sell books for travelers. For questions 1-15, choose from the shops (A-G). The shops may be chosen more than once. There is an example at the beginning.

Of which shop is the following stated?

1. No other shop in the country has as many maps and guides. B

2. The assistant found out about the writer's plans before making suggestions.

3. The assistants were very busy.

4. Despite its size. The shop is well-organized.

5. The writer liked the fact that it was quiet in the shop.

6 . Books the writer considered not very suitable were recommended to him.

7. The assistant did not know that the books on Orlando were kept in two places.

8. The books on Orlando were said to be of a similar quality to each other.

9. The shop had the best selection of books other than maps and guides.

10. The assistant tried to find out if any more books on Cuba were available.

11 . The shop is currently being made bigger.

12. The assistant recommended a book that the shop didn't have.

13. The size of the shop is one of its good points.

14. The assistant looked for information on books that don't exist.

15. The writer's request was treated as a matter of urgency.

\section{Buying travel Books}

I visited 7 bookshops around the country. I asked an assistant to recommend a detailed, critical guide to Orlando in Florida, USA, and to make some suggestions for general reading about Cuba.

Shop A: A joy for three reasons: firstly, the spacious shop and its hushed, library- like atmosphere; secondly, the country- by -country layout; and thirdly, the extensive range of general material on each country. Other shops have a better stock of maps and guides, but not of country- related novels, biographies, cookery and history books. There is a second hand section on the top floor. There was a moderate selection of Orlando guides; The Unofficial Guide was given top recommendation, although it was not in the stock. There was an excellent choice of reading on Cuba, including an anthology of Cuba writers.

Shop B: The strength of the shop lies in its range of maps and guides - both unequelled in Britain. Its UK department is divided into regions, with excellent themed sections on every thing from climbing to canals. However, travel-related literature is limited. There were only three Orlando guides in stock and I was told that there was ' not much to choose between them'. As for Cuba, I was told ' there really isn't much general reading matter'. In fact, they had only three books on the island in the stock.

Shop C: A relatively small shop with a casual atmosphere. Most books are arranged by country. The diversity of reading mater- not just current travel- writing, but fiction, biography and valuable old guides- make browsing an adventure. Hearing my inquiry, the assistant rushed around as if her life depended on it. Fourteen Orlando guides were in stock and the Unofficial guide was recommended. I could find only two general books on Cuba, but checks were made on the computer and in the travel-writing section for others.

Shop D: In this monumental building, the travel department comprises a map section, guides and a fairly limited travel-writing section. Staff was pressed for time because there was no help desk and customers were waiting to pay for books. There was a guide choice of Orlando guides, but the assistant picked out two of the least appropriate. As for Cuba, he suggested a certain novel and referred me to the shop's history department. He failed to mention The Land of Miracles, which was the only relevant title I actually found there.

Shop E: There were a large range of guides. Some mainstream travel-writing at some maps at one of its branches and an impressive heap selection a smaller choice of guides and no travel-writing at the other. The branches are three minutes' walk apart and staff offer to check what is in other branches, but the split is thoroughly unhelpful. There was a good selection of Orlando guides, but the assistant didn't check the shelves (The Unofficial Guide was there), and instead used the computer to try to find guides that have never in fact been published. For Cuba, travel literature is arranged by author. No recommendations were offered; instead, some seventy titles were brought up on the computer.

Shop F: The shop had a large, well laid-out stock of maps and guides, and an extensive collection of general reading material. The owners are extending the shop but work should have finished in six weeks. Eighteen Orlando guides were in stock. The assistant asked detailed questions about my trip and then made recommendations. For Cuba, she picked out The Land of Miracles (the only general reading on Cuba in stock), and suggested I look in the shop's history selection.

Shop G: Although hardly bigger than a large sitting room, it is orderly, maximizes its space and has a good range of guides. There is a limited travel-writing section filled by author. There was a good selection of Orlando guides, but some were filled under ' $\mathrm{F}$ ' for Florida and others under ' $\mathrm{O}$ ' for Orlando. The assistant found only the latter and missed the others. I was told, incorrectly, that there was nothing on Cuba in the travel-writing section. Instead, I was directed to 
the regional studies department, which had more than a dozen relevant historical and political books, but nothing specifically about travel.

Part 2

You are going to read a newspaper article about a couple and their unusual way of life. Choose the most suitable heading from the list A-I for each paragraph (1-7) of the article. There is one extra heading which you don't need to use.

A: not every one's choice

B: striking a balance

C: spreading the message

D: taking on a role

E: interesting objects

$\mathrm{F}$ : a life long interest

G: knowing where to look

$\mathrm{H}$ : a gloomy look

I: keeping away from modern technology

In their own time

John Holt meets a couple who are trying to re-create the style of the 1940s in their own home.

0: I

Steve and Marylin Saunders are a couple with a difference. They don't want washing machines, dish washers, satellite dishes or computers. Instead, they are nostalgic for an age they never knew, and their dream is to head back to the 1940s.

1: Trapped in the modern times, however, they've had no choice but to do the next best thing and turn their home into a living museum. The look they've spent so long creating is intended to be a re-enactment of the past. Steve and Marylin enjoy acting the part, to the point where both dress in authentic forties clothing, right down, apparently, to their underwears.

2: 'It was the clothes which initially started my interest in the period', says Maryln. That was sixteen years ago, just after they got married and gradually the interest turned into an obsession as more and more items for the forties were acquired from searching through jumble sales and antique stalls to replace their modern possessions.

3: The problem was that all this period style was coming together in an inappropriately modern house. Something had to be done and the house was put up for sale. Ironically, however, all that hard work spent re-creating the 1940s meant that the young buyers who came viewing were scared away. 'They couldn't understand why it looked so different', says Marylin, 'and it took us two years to sell in the end'.

4: The authentic 1940s color scheme is now applied to a more suitable house. 'The kitchen is full of dark yellow and green', says Marylin, ' and the rest of the house features brown. We've also used a lot of special paint called distemper which comes in only one color, a moldy green. It all helps to develop the right kind of depressing feel which was so typical of the period.

5: The accessories which decorate the house add the telling touches: there is the classic old telephone, oval mirrors and a polished wooden clock. The star attraction is a working 1949 television set bought for $\$ 350$. 'The house had most of its period features, such as the doors, says Marylin, ' but the bathroom was painted a nasty 1960s pink. We've now put in an original Art Deco bath and sink, and the period tiles complete the look'.

6: Compromises with the modern world have had to be made, but they make sure these have been kept to a minimum. They have a video, but use it only to watch films appropriate to the time. They also have a CD player, but it's used only to provide thirties and forties music.

7: Their interest in the music from the past has led them to set up a series of forties-style dances in the area, where everyone is encouraged to come in the period dress. These have been so successful that the couple has started a 1940s society. It may be an advanced form of escapism, but for some the future is definitely in the past.

\section{APPENDIX B: THE SHORT STORIES}

\section{The Wedding Gift}

Ray's wedding had gone off without a hitch. Everyone seemed to have had a good time. A few people had too good of a time; they went home with designated drivers. All evening, the gift table remained unguarded. Who would steal anything, Ray thought. He had never heard of such a thing happening at a wedding. But his best friend, Aaron said there was a first time for everything. He strolled out regularly from the inside festivities to check on the gift table, making sure no one suspicious was hanging around it.

Ray and Julia went on a three-week honeymoon to Italy right after the wedding. When they got back, they opened all the gifts and sent out thank you notes. But there was one problem. A married couple that used to be good friends had apparently given nothing. This surprised Julia, because Walt and Marry said they were thrilled to be invited. And, they actually seemed to have had a great time at the wedding. Frankly, Ray didn't even care if they hadn't given a gift. He just needed to know whether to send a thank you note. Ray called Aaron. Aaron said may be Walt had left an envelope on the gift table like Aaron had. "Yes but we got your envelope with the cash inside," Ray said. 
"Maybe my envelope looked too thin, and some thief thought Walt's envelope looked nice and fat".

\section{Text 1}

\section{Carbon Monoxide}

Helen stepped outside her front door to see what the weather was like. It was sunny and warm. That was nice, because for the past two weeks it had been cold and rainy. It had been so cold that she had had to turn her heater on. She was lucky, because her heater worked and she could pay her heating bills.

Some people in Los Angeles were not so lucky. Unable to use their home heaters, they placed charcoal into a barbecue grill and lit it. The heat kept them warm, but the carbon monoxide killed them. This happens almost every winter in Los Angeles. People shut all the windows tight to keep the cold out, and then light the charcoal. Soon enough, the oxygen in their home is consumed by the open flames. The family suffocates to death

Everyone knows that smoke detectors are required in Los Angeles. But many people don't know about, or think they need, carbon monoxide detectors. They're not expensive. A \$25 investment can save a family from death. People always think that nothing bad will happen to them; it always happens to " the other guy". So they forget to put fresh batteries into their smoke detectors annually, and they don't bother to buy carbon monoxide.

Text: 2

\section{Monkeys Cause Man's Death}

A florist in Delhi, India fell to his death after he was attacked by a gang of monkeys. He was on his balcony watering his plants. Three monkeys, which usually were friendly beggars, sat on his balcony railing and watched. They were hoping that he would offer them some food. When he finished watering the plants, he sat down in a chair to enjoy the sunset.

The monkeys waited a minute. When they realized that he was not going to feed them anything, they leaped on him. They scratched his face and pulled at his hair and his clothes. Bleeding and screaming, he panicked. Instead of going back into his apartment through the sliding glass door, he leapt off his balcony. He lived on the second floor; it was only ten feet to the pavement below. However, he struck the pavement head first, immediately breaking his neck.

The monkeys jumped to the pavement. They dug through his shirt and pants pockets looking for food. One monkey took off with his keys. As humans destroy the forests in India, monkeys like these are getting hungrier and more aggressive.

"Our monkeys are getting out of control," said a neighbor. He said he had already barricaded his balcony with barbed wire. "It's ugly, I must admit. A balcony shouldn't look like the outside of a prison. My neighbors want me to take it down. They say the barbed wire might injure the monkeys and it's unsightly. But I'll bet that some of my neighbors will be going to the hardware store tomorrow".

\section{Text: 3}

\section{The Spitter}

Rudy and Brenda were walking on the sidewalk, approaching the coffee shop. A young man was sitting at an outside table. There were four chairs at the table, but he was by himself. Just before Rudy and Brenda got up to his table, the young man spit on the sidewalk. Rudy said to Brenda, "watch out for the spit," and glared at the young man.

How dare he spit on the side walk just as Rudy and Brenda were approaching? But there was nothing Rudy could say in front of Brenda- she would get angry. She was always telling him to ignore jerks. So he ignored this jerk. They found a nearby table with only one chair. Rudy grabbed a chair from the young man's table, and he sat down.

Rudy went around the corner to buy a newspaper from the newsstand. When he returned, he noticed that the young man was gone. Rudy asked Brenda what she wanted to drink. She said she wasn't thirsty. He walked inside to get himself a coffee. Surprised, he saw that the person behind the counter was the spitter from outside.

"You work here?" Rudy asked.

"What does it look like?" the young man said.

"Where's your supervisor?" Rudy asked.

"He is on break", the young man said. He definitely had an attitude, Rudy thought. Rudy ordered an extra large orange juice and an extra large latte. A few minutes later, the young man placed them on the counter and said, "Eight dollars".

Rudy asked for a small cup of water with ice. When the young man turned around to put the ice into a cup, Rudy knocked both of his extra large drinks over. The latte spilled onto the counter and then onto the floor behind the counter. The orange juice spilled into the tip basket, which was full of coins and bills. The young man turned around, looked at the mess, and glared at Rudy. Rudy said, "Forget the water," and walked out.

\section{REFERENCES}

[1] Avila, E. \& M. Sadoski. (1996). Exploring new applications of the key word method to acquire English vocabulary. Language learning, 46, 379- 395.

[2] Babaei, N, and Riazi, A. (2008). Iranian EFL Female Students' Lexical Inferencing and its Relationship to Their L2 Proficiency and Reading Skill. Reading Matrix, 8, pp.186-196.

[3] Bensoussan, M., \& Laufer, B. (1984). Lexical guessing in context in EFL reading comprehension. Journal of Research in Reading, 7, 15-31.

[4] Brown, G., \& Yule, G. (1983). Discourse analysis. Cambridge: Cambridge University Press. 
[5] Chern, C. (1993). Chinese students. word-solving strategies in reading in English. In T. Huckin, M. Haynes, \& J. Coady (Eds.), Second language reading and vocabulary learning (pp. 67-85). Norwood, NJ: Ablex.

[6] Chi, F.m., \& Chern, C.-1. (1988). The study of English teaching and learning in senior high school. In the proceedings of the sixth conference on English teaching and learning in the Republic of China (pp. 95-109). Taipei: Crane Publishing Company.

[7] Day, R. R., Omura, C., \& Hiramatsu, M. (1991). Incidental EFL vocabulary learning and reading. Reading in a foreign language, 7, 541-551.

[8] Durkin, D. (1989). Teaching them to read $\left(5^{\text {th }}\right.$ ed.). New York: Allyn \& Bacon.

[9] Goodman, K. (1967). Reading: A psycholinguistic guessing game. Journal of the Reading Specialist., 6(1), 126-135.

[10] Goodman. (1971). Psycholinguistic universals in reading process, in Paul Pimsleur and T.Quinn (eds.), The Psychology of Second Language Learning. Cambridge: Cambridge University Press.

[11] Grabe, William. (1991). Current developments in second language reading research. TESOL Quarterly. 25 (3): 375-406.

[12] Haastrup, K. (1990). Developing learners' procedural knowledge in comprehension. In R. Phillipson, E. Kellerman, L. Selinker, M. Sharwood Smith, \& M. Swain (Eds.), Foreign/second language pedagogy research (pp. 120-133). Clevedon, UK: Multilingual Matters.

[13] Haynes, M. (1993). Patterns and perils of guessing in second language reading. In T. Huckin, M. Haynes, \& J. Coady (Eds.), Second language reading and vocabulary learning (pp. 46-62). Norwood, NJ: Ablex.

[14] Huckin, T. \& J. Bloch. (1993). Strategies for inferring word meaning from context: A cognitive model: In T. Huckin, M. Haynes, \& J. Coady (Eds.); Second language reading and vocabulary learning (pp.153-178). Norwood, NJ: Ablex.

[15] Hunt, A. \& D. Beglar (2005). "A framework for developing EFL reading Vocabulary”. Reading in a Foreign Language, 17, 131.

[16] İstifçi, İ. (2009). Lexical inferencing strategies of Turkish EFL learners. Journal of Language and Linguistic Studies, 5(1), pp. 97-107.

[17] Kern, R. G. (1989). Second Language Reading Strategy Instruction: Its Effects on Comprehension and Word Inference Ability. The Modern Language Journal, V.73 (2), pp.135-149.

[18] Kess, J. F. (1992). Psycholinguistics: Psychology, linguistics and the Study of Natural Language. Amsterdam / Philadelphia: John Benjamins.

[19] Kruse, A. F. (1979). Vocabulary in context. ELT Journal, 33(3), 207-213.

[20] Laufer, B., \& Hulstijn, J. H . (2001). Incidental vocabulary acquisition in a second language: the construct of task-induced involvement. Applied linguistics, 22. 1-26.

[21] Lawson, M. J. \& D. Hogben. (1996). The Vocabulary Learning Strategies of Foreign-Language Students. Language Learning, V. $46(1)$, pp. 101-135.

[22] Lee, J., \& Wolf, D. (1997). A quantitative and qualitative analysis of word-meaning inferencing strategies of L1 and L2 readers. Spanish Applied Linguistics, 1, 24-46.

[23] Levin, J., Pressley, M., McCormick, C., Miller, G. \& Shriberg, L. (1979). Assessing the Classroom potential of the keyword method. Journal of Educational Psychology, 71, 583-94.

[24] Levine, A. \& Reves, T. (1990). Does the method of vocabulary presentation make a Difference? TESOL Canada Journal 8, 37 51.

[25] Mikulecky, B. (1990). A short course in teaching reading skills. Reading, MA: Addison - Wesley.

[26] Nagy, W. (1997). On the role of context in first- and second-language vocabulary Learning. In N. Schmitt \& M. McCarthy (Eds.), Vocabulary: Description, Acquisition and pedagogy (pp. 64-83). Cambridge: Cambridge University Press.

[27] Nassaji, H. (2004). The relationship between depth of vocabulary knowledge and L2 learners" lexical inferencing strategy use and success. The Canadian Modern Language Review, 61 (1), 107-134.

[28] Nassaji, H. (2006). The Relationship Between Depth of Vocabulary Knowledge and L2 Learners' Lexical Inferencing Strategy Use and Success. The Modern Language Journal, 90, pp. 387-401.

[29] Nation, I.S.P. (1990). Teaching and learning vocabulary. New York: Newbury House.

[30] Oxford, R. (1990). Language Learning Strategies: What Every Teacher Should Know. Massachusetts: Heinle \& Heinle.

[31] Paribakht, T. S. \& M. Wesche. (1999). Reading and "Incidental" L2 Vocabulary Acquisition: An Introspective Study of Lexical Inferencing. Studies in Second Language Acquisition, 21, pp. 195-224.

[32] Richards, J. C. (1991). The Context of Language Teaching. Cambridge: CUP.

[33] Richards, J. C., J. Platt and H. Weber. (1985). Dictionary of Applied Linguistics. Essex: Longman, p.43.

[34] Robinson, R., \& Good, T. L. (1987). Becoming an effective reading teacher. New York: Harper \& Row Publishers.

[35] Schmitt, N \& Meara, P. (1997). Researching Vocabulary through a word knowledge framework: Word associations and verbal suffixes. Studies in Second Language Acquisition,19,17-36.

[36] Seibert, L. C. (1945). A study on the practice of guessing word meanings from a Context. Modern Language Journal, 29, $296-$ 322 .

[37] Stein, M. (1993). The healthy inadequacy of contextual definition. In T. Huckin, M. Haynes, \& J. Coady (Eds.), Second language reading and vocabulary learning (pp. 203-212). Norwood, NJ: Ablex.

[38] Walker, L. J. A. (1981). Word-identification strategies of Spanish-speaking college students in reading English as a foreign language. Unpublished doctoral dissertation, the University of Texas at Austin.

[39] Yorio, Carlos A. 1971. Some sources of reading problems for foreign language learners. Language Learning, Vol.21, (1).107115.

Mansoor Tavakoli has a Ph. D in applied linguistics. He has been teaching TEFL courses for seventeen years at the University of Isfahan. His research interests are: language assessment, second language acquisition, and language teaching methodology. He has also published several articles in these areas. 
Samira Hayati has an MA in TEFL. She has been teaching English courses for six years at several institutes. Her research interests are: reading comprehension, vocabulary learning, and foreign language teaching and learning. She has also presented some articles in different conferences. 